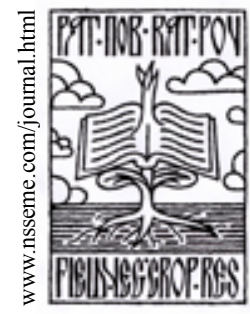

\title{
Effect of Soybean Seed Priming on Germination and Vigour Depending on the Seed Lot and Sowing Date
}

\author{
Zlatica Miladinov • Svetlana Balešević Tubić • Vuk Đorđević • \\ Vojin Đukić • Aleksandar Ilić • Lazar Čobanović
}

\author{
received: 8 August 2014, accepted: 8 October 2014 \\ published online: 30 October 2014 \\ (c) 2014 IFVC \\ doi: $10.5937 /$ ratpov51-6572
}

\begin{abstract}
Summary: The objective of this paper was to examine the effect of seed lot, sowing date, and priming on germination and vigour of soybean seed. Three different seed lots of an old soybean variety (Lot 1, Lot 2, Lot 3) created at the Institute of Field and Vegetable Crops in Novi Sad were used. There were three sowing dates: 10 April, 20 May and 20 June. $\mathrm{KNO}_{3}(1 \%), \mathrm{H}_{2} \mathrm{O}_{2}(0.1 \%), \mathrm{GA}_{3}(0.075 \%)$ and distilled water were used as primers. The results showed that soaking the seed prior to sowing, so called priming, positively affected seed germination and vigour in all three lots and with all three sowing dates. The best effect was accomplished with Lot 1 and sowing on the third date. With regards to primers, the best effect was achieved with the application of $\mathrm{KNO}_{3}$ and $\mathrm{H}_{2} \mathrm{O}_{2}$ solutions. Research has shown that even soaking the seed in distilled water, which is a simple, cheap, and ecological method of priming, in most cases leads to improvement of germination and vigour of soybean seed.

Keywords: germination, priming, seed lot, seed vigour, sowing date, soybean
\end{abstract}

\section{Introduction}

Soybean (Glycine max (L.) Merr.) belongs to leading plant species, not only in agricultural production but in industry processing as well. It is in the fourth place by production areas in the world (Balešević-Tubić \& Miladinović 2014). Soybean is grown in different agro-ecological conditions, thus seed germination and vigour are affected by various unfavourable environmental factors such as drought, extreme temperatures, untimely sowing, etc. (Casenave \& Toselli 2007). One of the methods which can overcome this problem is priming, i.e. soaking the seed prior to sowing (Ashraf \& Foolad 2005). Seed priming is a process which leads to fast and even germination and sprouting with the aim of achieving high vigour and better yield. This process has practical agronomic significance, especially in unfavourable environmental conditions, such as high salinity content in soil (Foti et al. 2008), low and high temperatures (Wahid \& Shabbir 2005),

Z. Miladinov* • S. Balešević Tubić • V. Đorđević • V. Đukić • A. Ilić - L. Čobanović

Institute of Field and Vegetable Crops, Maksima Gorkog 30, 21000 Novi Sad, Serbia

e-mail: zlatica.miladinov@nsseme.com and low relative soil moisture (Dul \& Tuong 2002). Additionally, seed priming leads to more effective water use due to more developed root system, bigger competitiveness over weeds, earlier flowering and maturation, increased resistance to some diseases and other. Priming ensures optimum running of molecular-biological processes during germination, stimulates activation of different enzymes, mobilizes proteins reserves and prepares cells for division (Soleimanzadeh 2013). This technology is mainly applied with vegetable crops (Basra 2004, Farooq 2006, Soltani 2001), and in some cases with field crops: wheat, sugar beet, maize, soybean, and sunflower (Khajeh-Hosseini et al. 2003). Priming partially hydrates the seed by the point when germination processes have been initiated but are not finished (Basra et al. 2005).

The aim of this study was to determine the best method for seed priming, depending on the seed lot and sowing date, as well as its effect on germination and seed vigour.
Acknowledgements:

This study has been supported by the Serbian Ministry of Education, Science and Technological Development through the project TR31022. 


\section{Materials and Methods}

In order to determine how priming of soybean seed sowed at different dates affects germination and seed vigour, the trial was carried out in 2014 at the experimental field of the Institute of Field and Vegetable Crops in Novi Sad, Serbia. Three different seed lots of an old soybean variety (Lot 1, Lot 2, Lot 3) were used in this trials. Experiment was set up in field conditions as randomized block design, with four replications, with distance of $50 \mathrm{~cm}$ between rows. One hundred soybean seeds were sown in each row. According to laboratory results obtained by using ISTA method (ISTA 2009), the lots had weaker germination probably because the seed was harvested with higher content of moisture in it, which had an effect on the reduced quality parameters. Germination in laboratory conditions of these lots was as follows: Lot 1: 78\%, Lot 2:75\%, and Lot 3: 76\%.

Soybean seed was soaked in primer and after six hours it was taken out and dried at $25^{\circ} \mathrm{C}$ until it reached the initial moisture, i.e. moisture which it had prior to soaking (Ahmadvand et al. 2012). Treatments used for seed priming included:

1. Potassium nitrate $\left(\mathrm{KNO}_{3}\right) 1 \%$

2. Hydrogen peroxide $\left(\mathrm{H}_{2} \mathrm{O}_{2}\right) 0.1 \%$

3. Gibberellic acid $\left(\mathrm{GA}_{3}\right) 0.075 \%$

4. Distilled water $\left(\mathrm{H}_{2} \mathrm{O}\right)$

5. Control - non-treated seed (C).

Seed was sown on three dates:

1. First date (10 April) - optimum date for sowing

2. Second date (10 May) - late sowing, e.g. due to re-sowing

3. Third date (20 June) - double cropping.
Germinated seeds were counted every 24 hours and the following characteristics were determined:

1. Germination - using the sum of effective temperatures needed for germination of soybean seed $\left(\sum 140{ }^{\circ} \mathrm{C}\right)$ (Todorovi \& Komljenović 2013).

2. Seed vigour - determined by the Germination index, i.e. everyday counting of completely normal seedlings in the period of 6 to 20 days from sowing and calculating as per the following formula:

$$
\text { Germination index }=\sum \mathrm{n} / \sum\left(\mathrm{n}_{\mathrm{n}} \mathrm{D}_{\mathrm{n}}\right) \times 100
$$

where $\mathrm{n}$ is the number of germinated seeds as of day $\mathrm{D}$, and $\mathrm{D}_{\mathrm{n}}$ is the number of days after sowing, until the total germination $\mathrm{n}$ is determined (Ranal $\&$ Santana (2006) cited by Kotowski).

Obtained results were statistically processed by the variance analysis of trifactorial split-splitplot experiment ( $\mathrm{A}$ - lot, $\mathrm{B}$ - sowing date, $\mathrm{C}$ priming). Data were processed by a computer software package Statistica 8, while ranking of significance of the obtained differences was determined by LSD (Least Significant Difference) test, for significance threshold 1\% $\alpha=0.01$ (Hadživuković 1991).

\section{Results and Discussion}

ANOVA results showed that seed lot had a significant effect on soybean seed germination while seed vigour was approximately the same (Figures 1 and 2). Significantly higher average germination was found in Lot 1 (71\%) with

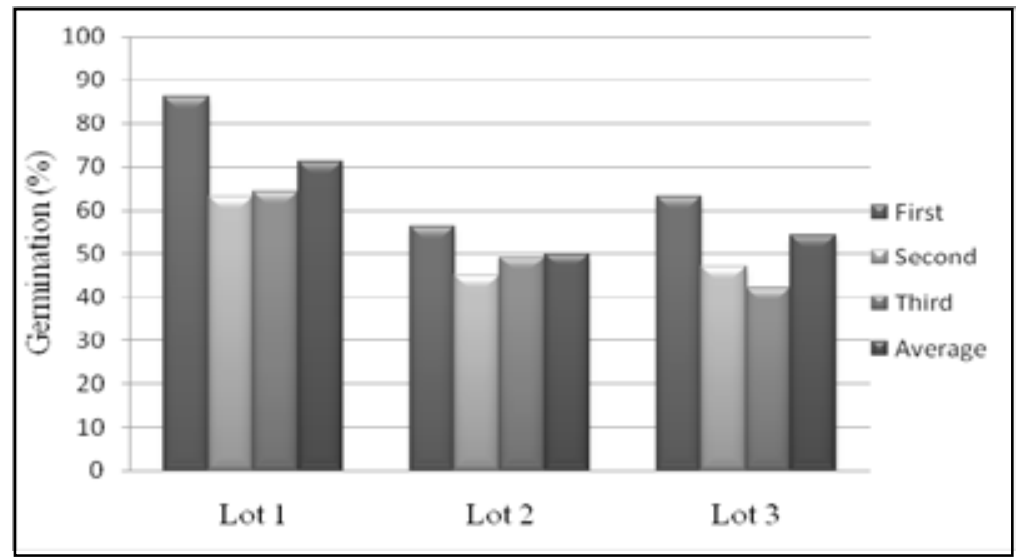

\begin{tabular}{|c|c|c|c|c|}
\hline \multirow{3}{*}{ LSD $_{0.01}$} & \multicolumn{2}{|c|}{ Lot } & \multicolumn{2}{c|}{ Lot $x$ Sowing date } \\
\cline { 2 - 5 } & Germination & Seed vigour & Germination & Seed vigour \\
\cline { 2 - 5 } & 2.03 & 0.77 & 3.07 & 1.15 \\
\hline
\end{tabular}

Figure 1. Effect of the lot and interaction with sowing dates on soybean seed germination (\%) 


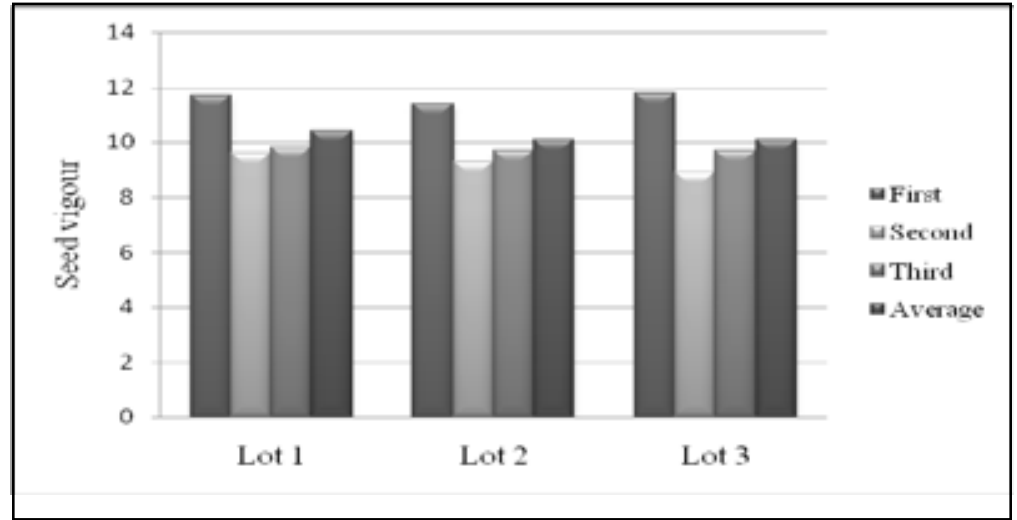

Figure 2. Effect of the seed lot and interaction with sowing dates on soybean seed vigour

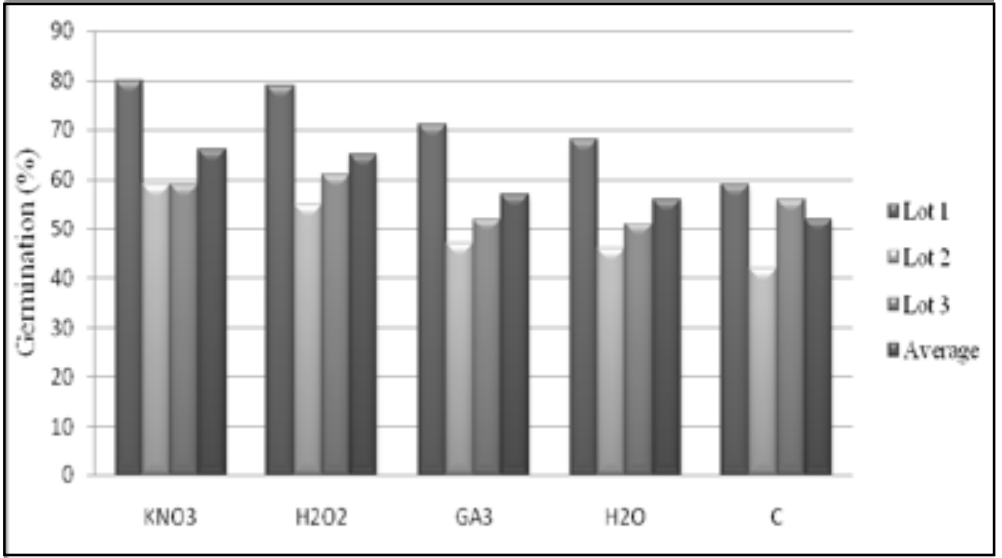

\begin{tabular}{|c|c|c|c|c|}
\hline \multirow{2}{*}{$\operatorname{LSD}_{0.01}$} & \multicolumn{2}{|c|}{ Priming } & \multicolumn{2}{c|}{ Priming $x$ Lot } \\
\cline { 2 - 5 } & Germination & Seed vigour & Germination & Seed vigour \\
\cline { 2 - 5 } & 1.37 & 0.57 & 3.33 & 1.23 \\
\hline
\end{tabular}

Figure 3. Effect of primers and interaction with lots on soybean seed germination (\%)

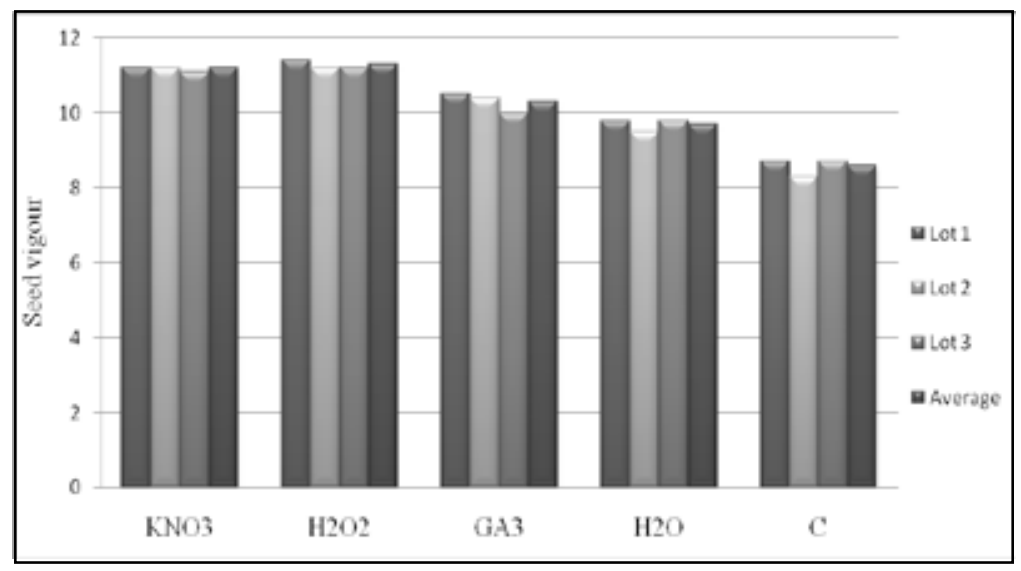

Figure 4. Effect of primers and interaction with lots on soybean seed vigour 
relation to Lot 2 (50\%) and Lot $3(54 \%)$. Similar to this, Miladinov et al. (2014) determined on a sunflower example that effect of treating the seed prior to sowing depends on the seed lot. All seed lots had approximately the same germination index, which means there were no significant differences in seed vigour.

By observing the interaction of seed lots and sowing dates, it can be concluded that the best germination and seed vigour were accomplished by sowing on the first date. Considering all sowing dates, Lot 1 had significantly higher germination with relation to other two lots, but vigour was approximately the same. By sowing it on the first date, Lot 1 achieved the best germination (86\%), while Lot 3 achieved the best germination index (11.8). By sowing on 10 May and on 20 June, Lot 1 had significantly better germination $(63 \%$ and $64 \%$, respectively) than the other two lots. The lowest germination was noted with the third date with Lot 3 (42\%) where the lowest germination index was determined, but with sowing on the second date (8.9). Results showed that the seed of the same plant species, but from different lots, sowed at different dates, showed different seed germination.

Figures 3 and 4 show that all primers significantly affected seed germination and vigour in relation to non-treated seed. Likewise, primers differed among themselves in efficiency. Soaking the seed prior to sowing in $\mathrm{KNO}_{3}$ and $\mathrm{H}_{2} \mathrm{O}_{2}$ led to average germination of $66 \%$ and $65 \%$, respectively, and sowing the non-treated seed led to germination of $52 \%$. Treating the seed with these primers gave significantly better results in seed vigour (11.2 and 11.3) with relation to other two primers and control variant (8.6). Taking wheat as an example, it was proven that the use of hydrogen peroxide solution stimulates germination and seed vigour since it improves activity of peroxidase enzyme (Liheng et al. 2009). Mohammadi \& Amiri (2010) proved positive effect of $\mathrm{KNO}_{3}$ on germination and vigour of the rapeseed seed. Similarly, Arin et al. (2011) determined improvement of onion seed germination, i.e. improvement of bean seed vigour by priming the seed with $\mathrm{KNO}_{3}$ solution prior to sowing (Umair et al. 2010). Application of $\mathrm{GA}_{3}$ led to better germination (57) and vigour (10.3) with relation to control variant. However, effect was significantly weaker with relation to solution of potassium nitrate and hydrogen peroxide. Seed priming of carrot, onion and tomato with gibberellic acid leads to increase of germination and seed vigour (Sedghi et al. 2008).
Soaking the seed in distilled water also leads to improvement of soybean seed germination and vigour, but less than when soaking it in other primers. Caseiro et al. (2004) determined positive effect of distilled water on onion seed germination. This primer accomplishes the weakest effect. Soaking the seed in distilled water in this experiment had the weakest effect than the other primers, since distilled water has zero osmotic potential, which decreases seed accessibility to water (Rdhan \& Yanaht 1982).

Significant difference was also found in interaction between all lots and primers relative to control. Soaking the seed prior to sowing in $\mathrm{KNO}_{3}$ and $\mathrm{H}_{2} \mathrm{O}_{2}$ solutions gave the best results with all three lots. Treating the seed with $\mathrm{KNO}_{3}$ solution accomplished $80 \%$ germination with Lot 1 . Likewise, potassium nitrate also achieved the best effect with Lot 2 (59\%) while the best effect with Lot 3 was achieved when hydrogen peroxide (61\%) was used.

The best vigour was determined with Lot 1 with the application of hydrogen peroxide solution (11.4). Similarly, Dezfuli (2008) reported that interaction of different genotypes and pre-sowing treatments had different effects on germination and seed vigour. Poštić et al. (2011) reported that faster seed germination in the field dictates better and more even sprouting of plants, rich development, and greater resistance to environmental conditions, diseases and pests since more developed plants are more resistant. Moreover, faster germination increases the competition over weeds (Maurmicale \& Cavallaro 1996).

Soybean seed germination and vigour also depend on the time of sowing (Figures 5 and 6). Significantly better value of these parameters was accomplished with sowing on the first date (68\% and 11.6). The lowest germination and seed vigour were noted with the second date (51\% and 9.2). Agrometeorological conditions in Serbia (soil temperature and soil moisture content) in the middle of June were extremely favourable for soybean seed germination and sprouting compared to the second sowing date.

Significant effect was also found with interaction between sowing dates and primers. The effect of priming with $\mathrm{KNO}_{3}$ and $\mathrm{H}_{2} \mathrm{O}_{2}$ on germination was largest with late sowing dates, and it decreased as it neared optimum sowing date. Furthermore, the effect of priming on vigour was largest with the third sowing date, with all the primers, but with $\mathrm{KNO}_{3}$ and $\mathrm{H}_{2} \mathrm{O}_{2}$ being the best. 


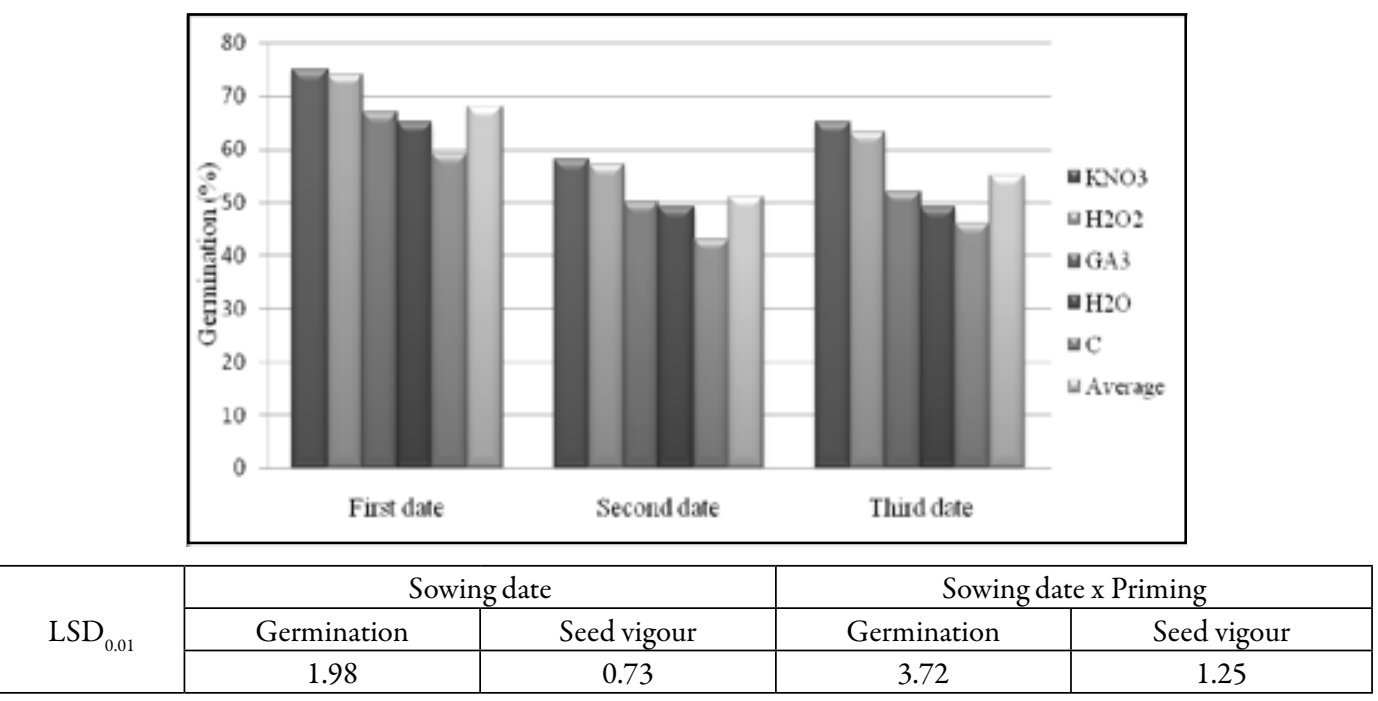

Figure 5. Effect of sowing dates and interaction with primers on soybean seed germination (\%)

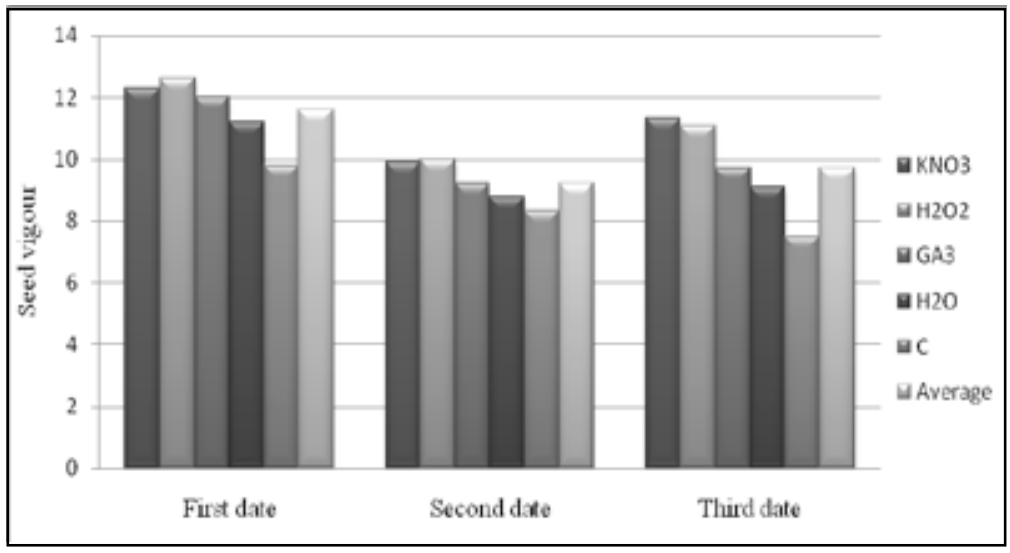

Figure 6. Effect of sowing dates and interaction with primers on soybean seed vigour

Mohammadi (2009) reported that soaking seed in potassium nitrate had the best effect on germination and soybean seed vigour with late sowing. If germination and root development progress faster, better survival is possible, since in this way better absorption of moisture from deeper parts of soil is established (Livingston 1990).

\section{Conclusions}

These results lead to the conclusion that the use of different primers caused increase of seed germination and vigour, principally in late sowing. The best results were obtained with the application of potassium nitrate and hydrogen peroxide solutions. Studies have shown that even soaking the seed in distilled water, which represents simple, cheap and ecological way, in most cases leads to improvement of soybean seed germination and vigour.

\section{References}

Ahmadvand, G., Soleimani, F., Bijan Saadatian, B., \& Pouya, M. (2012). Effects of seed priming on germination and emergence traits of two soybean cultivars under salinity stress. J. Basic Appl. Sci. Res. 3, 234-241.

Arin, L., Polat, S., Deveci, M., \& Salk, A. (2011). Effects of different osmotic solutions on onion seed emergence. Afr. J. Agric. Res., 6, 986-991.

Ashraf, M., \& Foolad, M. R. (2005). Pre-sowing seed treatment: A shotgun approach to improve germination plant growth, and crop yield under saline and non-saline conditions. $A d v$. Agron. 88, 223-271.

Balešević-Tubić, S., \& Miladinović, J. (2014). Semenarstvo soje. Institut za ratarstvo i povrtarstvo, Novi Sad. 
Basra, S. M. A., Farooq, M., Hafeez, K., \& Ahmad, N. (2004). Osmohardening - a new technique for rice seed invigoration. Inter. Rice Res. Notes 29, 80-81.

Basra, S. M. A., Afzal, I., Rashid, A. R., \& Farooq, M. (2005). Presowing seed treatment to improve germination and seedling growth in wheat (Triticum aestivum L.). I Cadernode Pesquisa Ser. Bio., Santa Cruz de SuI., 17, 155-164.

Caseiro, R., Benett, M. A., \& Marcos-Filho, J. (2004). Comparison of three priming techniques for onion seed lots differing in initial seed quality. Seed Sci. Technol. 32, 365-375.

Casenave, E. C., \& Toselli, M.E. (2007). Hydro priming as a pretreatment for cotton germination under thermal and water stress conditions. Seed Sci. Technol. 35, 88-98.

Dezfuli, P. M., Sharif-Zadeh, F., \& Janmohammadi, M. (2008). Influence of Priming Technique on Seed Germination Behaviour of Maize Inbred Lines (Zea mays L.). ARPN J Agric. Biol. Sci. 3, 22-25.

Dul, L. V., \& Tuong, T. P. (2002). Enhancing the performance of dry-seeded rice: effects of seed priming, seedling rate, and time of seedling. pp. 241-256. In: S. Pandey, M. Mortimer, L. Wade, T. P. Tuong, K. Lopes and B. Hardy (Eds), Direct Seeding: Research Strategies and Opportunities. International Research Institute, Manila, Philippines.

Farooq, M., S. M. A. Basra, S. M. A., \& Haffez, K. (2006). Rice seed invigoration by Osmohardening. Seed Sci. Tech. 34, 181186.

Foti, R., Abureni, K., Tigere, A., Gotosa, J., \& Gere, J. (2008). The efficacy of different seed priming osmotica on the establishment of maize (Zea mays L.) caryopses. J. Arid Envir. 72, 1127-1130.

Hadživuković, S. (1991). Statistički metodi. Poljoprivredni fakultet, Novi Sad.

ISTA (2009): International Rules for Seed Testing. International Seed Testing Association, Switzerland.

Khajeh-Hoseini, M., Powell, A. A., \& Bingham, I. J. (2003). The interaction between salinity stress and seed vigour during germination of soyabeans. Seed Sci. Tech. 31(3), 715-725.

Liheng, H., Zhiqiang, G. \& Runzhi, L. (2009). Pretreatment of seed with $\mathrm{H}_{2} \mathrm{O}_{2}$ enhances drought tolerance of wheat (Triticum aestivum L.) seedlings. African J. Biotechnol. 8(22), 61516157.
Maurmicale, G., \& Cavallaro, V. (1996). Effect of seed osmo-priming on germination of three herbage grasses at low temperatures. Seed Sci. Technol. 24, 331-338.

Miladinov, Z., Radić, V., Miklič, V., Crnobarac, J., Balalić, I., Jocković, M., \& Mrđa, J. (2014). Uticaj biostimulatora na energiju klijanja i klijavost semena suncokreta. Ratar. Povrt. 51, 29-37.

Mohammadi, G. R (2009). The effect of seed priming on plant traits of late-spring seeded soybean (Glycine max L.). Am. Eur. J. Agric. Environ. Sci. 5, 322-326.

Mohammadi, G. R., \& Amiri, F. (2010). The effect of priming on seed performance of canola (Brassica napus L.) under drought stress. Am. Eur. J. Agric. Environ. Sci. 9, 202-207.

Poštić, D., Momirović, N., Broćić, Z., Dolijanović, Ž., Trkulja, N., Dolovac, N., \& Ivanović, Ž. (2011). Ocena kvaliteta semena paradajza (Lycopersicum esculentum L.). Zbornik naučnih radova Instituta PKB Agroekonomik, 17, 131-135.

Ranal, M. A., \& Santana, D. G. (2006). How and why to measure the germination process? Revista Brasileira de Botânica 29, 1-11.

Rdhan, J., \& Yanaht, V., (1982). Note on the salt tolerance of some rice varieties of Andra Pradesh during germination and early seeding growth. Indian J. Agric. Sci. 52, $472-474$.

Sedghi, M., A. Gholipouri, A., \& Seyed Sharifi R. (2008). $\gamma$-Tocopherol accumulation and floral differentiation of medicinal pumpkin (Cucurbita pepo L.) in response to plant growth regulators. Not. Bot. Hort. Agrobot. Cluj. 36, 80-84.

Soleimanzadeh, H. (2013). Effect of seed priming on germination and yield of corn. Intern.J. Agric. Crop Sci. 366-369.

Soltani, A., Galeshi, S. Zenali, E., \& Latifi, N. (2001). Germination seed reserve utilization and Growth of chickpea as affected by salinity and seed size. Seed Sci. Tech. 30, 51-60.

Todorović, J., \& Komljenović, I. (2013). Leguminoze. Poljoprivredni fakultet, Banjaluka, Bosna i Hercegovina.

Umair, A., Ali, S., Bashir, K., \& Hussain, S. (2010). Evaluation of different seed priming techniques in mung bean (Vigna radiate). Soil Environ., 29, 181-186.

Wahid, A., \& Shabbir, A. (2005). Induction of heat stress tolerance in barley seedlings by pre-sowing seed treatment with glycinebetaine. Plant Growth Regul. 46, 133-141.

\title{
Uticaj potapanja semena soje na klijavost i životnu sposobnost u zavisnosti od partije i roka setve
}

\author{
Zlatica Miladinov • Svetlana Balešević Tubić • Vuk Đordević • \\ Vojin Đukić • Aleksandar Ilić • Lazar Čobanović
}

\begin{abstract}
Sažetak: Cilj ovog rada bilo je ispitivanje uticaja partije, rokova setve i rastvora za potapanje na klijavost i životnu sposobnost semena soje. Kao materijal poslužile su tri partije semena soje (partija 1, partija 2, partija 3) stvorene u Institutu za ratarstvo i povrtarstvo u Novom Sadu. Setva je izvršena u tri roka: 10. aprila, 20. maja i 20. juna. Kao rastvori za potapanje korišćeni su $\mathrm{KNO}_{3}(1 \%), \mathrm{H}_{2} \mathrm{O}_{2}(0,1 \%), \mathrm{GA}_{3}(0,075 \%)$ i destilovana voda. Rezultati su pokazali da je potapanje semena pre setve (prajmiranje) imalo povoljan uticaj na klijavost i životnu sposobnost semena kod sve tri partije, ali i kod sva tri roka setve. Najbolji efekat ostvaren je kod partije 1 i setvom u trećem roku. Primenom rastvora kalijum-nitrata, odnosno vodonikperoksida postignut je najbolji efekat. Istraživanja su pokazala da čak i potapanje semena u destilovanu vodu, što predstavlja jednostavan, jeftin i ekološki metod, u većini slučajeva dovodi do poboljšanja klijavosti i životne sposobnosti semena soje. Ključne reči: klijavost, partija semena, potapanje, rok setve, soja, životna sposobnost semena
\end{abstract}

